\title{
New taxonomy of relationship value and the moderating effect of relationship age: An empirical
} study in manufacturer-retailers partnership

\author{
Prita Prasetya $^{a, b^{*}}$, Mukhamad Najib ${ }^{c}$ and Agus W. Soehadid
}

${ }^{a}$ School of Business and Economics, Universitas Prasetiva Mulya, Indonesia

${ }^{b}$ PhD Alumni, School of Business, IPB University, Indonesia

${ }^{c}$ Associate Professor of Department of Management, IPB University, Indonesia

${ }^{d}$ Professor of School of Business and Economics, Universitas Prasetiya Mulya, Indonesia

\section{H R O N I C L E}

\section{Article history:}

Received: June 26, 2020

Received in revised format:

June 302020

Accepted: July 26, 2020

Available online:

July 26, 2020

Keywords:

Relationship value

Performance

Relationship age

Channel relationship

Retailer

\section{A B S T R A C T}

\begin{abstract}
This study aims to examine the effect of relationship value and test the moderating effect of relationship age on performance in a manufacturer-retailer relationship. Relationship value is identified from four dimensions - personal, financial, knowledge, and strategic value, each of which is indicated in different outcomes. This research presents a new taxonomy that can be used for manufacturers from retailers' perceptions of what counts as relationship value. Furthermore, this study explores the effect of relationship age on the relationship value and performance. Data were collected from 259 retailers from paint and chemical stores in Indonesia, through a structured questionnaire, and collected quantitative data were analyzed through structural equation modeling (SEM). The analysis of the sample suggests a positive relationship between relationship value and performance. This research shows the impact of relationship age into a short-term and long-term relationship. Relationship age did not strengthen the positive relationship between relationship value and performance. Findings suggest that manufacturers should invest more time and effort in relationship value drivers with their key retailers to enhance their relationships with those retailers.
\end{abstract}

C 2020 by the authors; licensee Growing Science, Canada

\section{Introduction}

The study of channel relations has become an important research area over the past decade. Marketing channels are one of the main functions in retail trade and become an important element in the value chain (Kotler 2000). Research on marketing channel management has proven the importance of managing relationships between individual or organizations that implement distribution functions (Weitz \& Jap, 1995). Management in managing marketing channels is the main issue faced by manufacturers. Since, the business goals have shifted just to gain wider profit, maintaining mutually beneficial relationships among business partners. Then, the manufacturer is required to focus on developing more relationships for the success of company's marketing activities (Stern \& Palmatier, 2014). The research that has been conducted represents that many companies move from transactional discretion to relational exchanges (Ganesan, 1994; Day GS 2000; Palmatier et al., 2006; Pimpa 2008; Nguyen \& Nguyen 2011; Leonidou et al., 2014). In business interaction, there are tiny pure transactions without the existence of a relational relationship. Moreover, the complexity of managing marketing channel management not only focuses on selecting distribution channel strategies but also maintains relationships among them. Buyer-seller relationship theory explains that establishing relationships among partners becomes an important focus, especially how these relationships are implemented (Dwyer et al., 1987). Indonesia is a country with rapid market development and makes this country one of the 'hot spots' of the world's economy. As an archipelago, Indonesia's business market is very complex and geographically dispersed. To access this market, the manufacturers operate close to their intermediaries or distributors. In turn, these 
distributors maintain close contact with their particular end-user market and with this consumer base. Therefore, each distributor contributes business value to their relationships with their partner manufacturers. Manufacturers create products that can be sold and distributed by distributors (Rosenbloom, 2013).

The study of the relationship between manufacturers and distributors in harmony is the key to success in business cooperation to improve performance. Likewise, in the Indonesian archipelago, the management of these manufacturers-distributor marketing channels remains a critical determinant of business success. Connectivity that is highly aligned throughout this marketing channel can increase manufacturer and distributors' market reach. Previous research into marketing channels is usually one-way from manufacturer-to-retailer or retailer-to-manufacturer. In Indonesia's context, marketing channel studies (example Puspitawati, 2011; Herlambang et al., 2006; Setyawan et al., 2013; Sukresna, 2015), are limited in the scope of the manufacturer and distributor. The study of marketing channel management has proved the importance of managing relationships between people or organizations that carry out the distribution function (Weitz \& Jap, 1995). Management in managing marketing channels becomes the main issue faced by the manufacturer. Because business objectives have shifted from the beginning to get benefits, maintaining a mutually beneficial relationship between business partners. Therefore, the manufacturer must focus on efforts to develop more relationships for the success of the company's marketing activities (Stern $\&$ Palmatier, 2014). Research that has been done represents that many companies move from discrete transactional exchanges to relational ones (Ganesan, 1994; Day GS, 2000; Palmatier et al., 2006; Pimpa 2008; Nguyen \& Nguyen 2011; Leonidou et al., 2014). In business, interactions rarely occur purely transactions without a relational relationship. The complexity of marketing channel management focuses not only on selecting distribution channel strategies but also on maintaining the relationship between the two. The buyer-seller relationship theory explains that establishing relationships between partners is an important focus, especially about how it is carried out (Dwyer et al., 1987). Based on the phenomena in the manufacturer and the retailer's current business relationship, the retailer will prefer the preferred manufacturer based on the value offered. Choosing the right manufacturer will help retailers improve their perception of the manufacturer's benefits if establishing a cooperative relationship. Therefore a better understanding of work relations between manufacturers and retailers is needed. An appropriate marketing strategy is needed to achieve optimal business performance by identifying factors that affect business performance, directly impacting strategy development.

This study was conducted to broaden the understanding of the impact of relationship value on business performance. Relationship values in most marketing literature focus on financial value and fail to provide a more comprehensive perspective. Thus, this study aims to develop an empirical-based taxonomy that explains various values that individuals associate with business relations. This study also discussed how relationship age moderation affects the relationship between relationship value and business performance. The study of relationship marketing also examines the age of a relationship or the duration of a relationship, i.e., the length of the relationship that occurs between partners (Palmatier et al., 2006). The empirical studies show that the duration of relationship and continuity is positively related to channel performance (Mehta et al., 2006; Lusch \& Brown, 1996). However, other empirical studies fail to explain the direct and indirect effects of the relationship's duration on performance (Chang \& Gotcher, 2010). Thus, further investigation is still needed to influence the duration of the relationship.

\section{Literature review and hypothesis development}

\subsection{Literature review}

The extensive literature on marketing channels has extensively examined how relationships and coordination between channel partners influence marketing performance from various theoretical perspectives (Anderson et al., 1994; Frazier, 2009), aiming to improve channel performance (Kang et al., 2018). However, there are still limited studies that comprehensively explain drivers that can improve business manufacturers' and retailers' performance. Customer value is the core of view of marketing and sales exchange that broadly considers this. The supplier will produce and deliver the goods or services that the customer wants and provide the highest profit. In the sales literature, companies create customer value by exchanging products and services that meet the perception of customer needs (Levitt, 1981). While in the relationship marketing literature, the company is focused on fostering mutually beneficial long-term customer relationships (Dwyer et al., 1987). In the supply and purchase chain literature, customer value is a central factor influencing source decisions (Wouters et al., 2005). Value concept in the literature shown in Table 1.

\section{Table 1}

Value concept in the literature

\begin{tabular}{|c|c|c|}
\hline Theory & Value concept & Author \\
\hline Social exchange Theory & Value is derived from social exchange between actors & Blau 1965 \\
\hline Classical economic theory & Values are subjectively derived from the subject itself & Marx 1967 \\
\hline Neo-classical economic theory & Value is derived from maximum utility and profit & Marx 1967 \\
\hline Transaction-cost economic theory & Value is derived from minimizing transaction costs & Williamson 1979 \\
\hline Exchange view of Marketing & Value is derived from the production and delivery of products and services to customers & Levitt 1981 \\
\hline Relationship Marketing & Value is derived from long-term customer relationships & Dwyer et al. 1987 \\
\hline Purchasing and supply chain & Value is derived from optimization in the search process & Wouters 2005 \\
\hline
\end{tabular}


Outlook changes in marketing are based on the concept of value. The higher the value expected or received, the stronger the motivation to start and maintain the relationships' exchange process. The concept of value is based on different assumptions. Two approaches to defining values are widely used by many researchers, including values based on products and the relational approach (Lindgreen \& Wynstra, 2005). Value is a core concept in marketing; creating superior customer value is the key to long-term survival and success for every business. There are many different perspectives on customer value in the business market (Glynn et al., 2012; Nguyen \& Nguyen, 2011; Ritter \& Walter, 2012). Traditionally, three perspectives have been found in the literature: the buyer's perspective, the creation of value through products and services, seller perspective, i.e., value creation through customer equity; and, buyer-seller perspective, as value creation through networks (Ulaga \& Eggert, 2006). Relationship value is expected to positively impact distributor performance, which can be defined as the real achievement that is felt, has resulted from the manufacturer-distributor relationship (Ford \& Mcdowell, 1999). Our study focuses on distributor performance in dealing with specific manufacturers, and distributor performance reflects sales growth, profit growth, product market share, and manufacturing logistics and inventory. The high relationship value felt by distributors leads to efficient transactions such as shortening response time, profits in logistics management, and marketing programs that contribute to distributors' efficiency and effectiveness in serving their customers' programs (Cannon \& Homburg, 2001; T. D. Nguyen \& Nguyen, 2011). These, in turn, can create a strong market position that will be reflected in distributor performance. When the conditions needed for high relationship values are met, the manufacturer or just the distributor or both are more likely to be interested in the existing relationship. Such a relationship can be expected to continue in the future, leading to increased mutual benefit through better understanding and customer service needs (Anderson \& Weitz, 2009; Nguyen \& Nguyen, 2014).

Table 2

Dimension of relationship value

\begin{tabular}{|c|c|c|}
\hline Author & Benefits Dimensions and Value Drivers & Sacrifice Dimensions \\
\hline Wilson \& Jantrania (1994) & $\begin{array}{l}\text { Performance, Product reliability, Technology, Social image, Time } \\
\text { to market, core competencies, knowledge, strategic fit }\end{array}$ & Price, acquisition cost, life cycle costs \\
\hline Anderson, J.C. \& Narus (1998) & $\begin{array}{l}\text { Economic benefits, Technical benefits, } \\
\text { Service benefits, Social benefits }\end{array}$ & Price \\
\hline Dyer \& Singh, (1998a) & $\begin{array}{l}\text { Knowledge sharing, Complementary } \\
\text { capabilities, Relation-specific assets }\end{array}$ & Partner scarcity \\
\hline Lapierre (2005) & $\begin{array}{l}\text { Product quality, Responsive, Technical } \\
\text { competence, Social Image, Trust, Product } \\
\text { Flexibility, Product customization, Solidarity }\end{array}$ & Price, Conflict, Energy, Time \\
\hline Ulaga \& Eggert (2005) & $\begin{array}{l}\text { Product features, Service and Know-how } \\
\text { benefit, Time-to- market, Social benefits }\end{array}$ & Price, Process cost \\
\hline Homburg et al. (2005) & $\begin{array}{l}\text { Product quality, Service quality, Flexibility of supplier, Commit- } \\
\text { ment of supplier }\end{array}$ & $\begin{array}{l}\text { Purchasing price, Acquisition costs, Opera- } \\
\text { tions costs }\end{array}$ \\
\hline Ulaga \& Eggert (2006) & $\begin{array}{l}\text { Performance, reliability, delivery, Product } \\
\text { offering, Service, Know-how, Time to } \\
\text { market, Delivery, Personal Interaction, } \\
\text { Responsive, Information Management }\end{array}$ & $\begin{array}{l}\text { Price, Acquisition, } \\
\text { competing alternatives, cost }\end{array}$ \\
\hline Lewin et al. (2008) & $\begin{array}{l}\text { Core benefits, Sourcing benefits (service efficiency, personal inter- } \\
\text { action), Operation benefits }\end{array}$ & Cost Advantage, Switching cost \\
\hline Lefaix-Durand et al. (2009) & $\begin{array}{l}\text { Product, Service, Delivery, Innovation, Time } \\
\text { to market, Personal interaction }\end{array}$ & $\begin{array}{l}\text { Direct, Acquisition, Operating cost, } \\
\text { Transaction, Psychological }\end{array}$ \\
\hline Čater \& Čater, (2009) & $\begin{array}{l}\text { Personal relations, Delivery and Service } \\
\text { support, Time-to-market, Product quality, } \\
\text { Supplier know-how. }\end{array}$ & Direct product costs. \\
\hline Nguyen \& Nguyen (2011) & $\begin{array}{l}\text { Product quality, information support, delivery performance, per- } \\
\text { sonal interaction }\end{array}$ & Not mention \\
\hline Cui \& Coenen (2016) & $\begin{array}{l}\text { Product quality, service delivery, supplier } \\
\text { Know how, core business support, } \\
\text { Troubleshooting support, Personal } \\
\text { interaction, Sustainability }\end{array}$ & Price, Process cost \\
\hline Skarmeas et al. (2015) & $\begin{array}{l}\text { Relational norms, Knowledge sharing, } \\
\text { complementary Capabilities, Relationship } \\
\text { specific assets }\end{array}$ & Not mentioned \\
\hline Ruiz-Martinez et al., (2018) & $\begin{array}{l}\text { Seller support, order delivery, product quality, personal training, } \\
\text { electronic notification, ICT benefit }\end{array}$ & ICT cost, low cost quality, customization \\
\hline
\end{tabular}

Marketing research expert continuously examines the constructs that build relationship values. Wilson and Jantrania (1994) studies found that value creation occurs in the social, economic, and political context in which the company located. Relationship value built from three dimensions, (i.e.) economic, behavioral, and strategic dimensions. Ford and Mcdowell (1999) assert that relationship value transcends financial problems resulting from the transfer of knowledge, reputation, and network access. Day (2000) asserts that strategic value and personal relationships are the basis for building a competitive advantage. Most of the marketing literature that deals with relationship value focus on the trade-off between benefits and sacrifice. Asserts that strategic value and personal relationships are the basis for building a competitive advantage. Most of the marketing literature that deals with relationship value focuses on the trade-off between benefits and sacrifices. Multiple relationship value dimensions were identified during the literature review, and it helped to understand the dimensions that make the rela- 
tionship value. The majority of the literature classified the value drivers as benefits or sacrifice. Table 2 indicates these dimensions from different works of literature. A more comprehensive perspective on building relationship value was developed by Biggemann and Buttle (2012). This research integrates the concept of value based on the relational approach, that relationship value in business is more than the concept of costs and benefits. The four factors driving relationship value are personal value, financial value, knowledge value, and strategic value.

Ford and Mcdowell (1999) define personal values as values that are connected with individual personal beliefs. Barnes (2003) refers to forms of value that are more central to the customer's feelings and emotions as emotional values. Personal value can be identified in episodes where one party legitimizes or accepts the other party's actions, which will be prohibited or disapproved under different circumstances. According to Biggemann and Buttle (2012), personal value is when one party approves or accepts the other party's actions in an unusual situation. Personal value indicators can be seen when the principal is more willing to help customers or provide tolerance in particular situations to prevent the relationship's termination. Besides, the personal value can be seen from customer retention and the existence of references from customers to other parties to the creation of financial value (Werner \& Kumar 2003). Financial value is defined as satisfaction associated with economic outcomes from relationships (Geyskens et al., 1998), and profitability relationships (Payne et al., 2008). Biggemann and Buttle (2012) study, a very close relationship with customers is an intangible asset and can be of financial value. The close relationship with partners will create partner confidence to obtain financial satisfaction with increased profitability (Storbacka, 1994).

Relationships can also provide value in the form of knowledge creation and transfer. It was generating new ideas, sharing more detailed information, or getting market intelligence to respond to demands better results from relationships that represent Knowledge-Based Values (Biggemann \& Buttle, 2012; Singh et al., 2018). Ballantyne (2004) research advice specialized knowledge of relationships as socially constructed and created together by people who interact. He stressed that the value of knowledge enables innovative solutions to emerge, increasing mutual understanding, and increasing trust. Strategic value results from increasing stability and decreasing uncertainty are given relationships to the parties involved, thus expanding the planning time horizon. These enable better planning, reduce risk, allow better utilization of assets, and provide a relationshipbuilding foundation. Strategic value exists if companies increase their competitiveness due to the relationships in which they are involved (Biggemann \& Buttle, 2012). The idea of benefiting from this expanded business network was identified by Anderson and Narus (1990) Anticipated Constructive Effects on Network Identity. Törrönen and Möller (2003) propose that the Supplier-Network Function access resources from an expanded network of suppliers.

\subsection{Development of research hypotheses}

The embedded relationship value will increase satisfaction between partners as reflected by an increase in business performance in increased profits and sales volume and financial performance. Research conducted (Li, 2010) examines the importance of relationship value in dyadic relationships between principal-agents in creating economic performance (market performance) and relational performance. Market performance is measured by sales growth, profit, and return on investment (ROI). Relationship performance is judged by the flexibility in dealing with unexpected fluctuations in demand, efficiency, and effectiveness. According to Walter et al. (2001), relationship value contributes to current product performance and future product market development, while also generating financial performance and relationship performance based on efficiency and effectiveness. The high relationship value felt by distributors leads to efficient transactions such as shortening response time, profits in logistics management, and marketing programs that contribute to the efficiency and effectiveness of distributors in serving their customers (Cannon \& Homburg, 2001; Nguyen et al., 2007; T. D. Nguyen \& Nguyen, 2011; Nguyen \& Nguyen, 2014). These, in turn, can create a strong market position that will be reflected in distributor performance. When the conditions needed for high relationship values are met, the manufacturer or distributor (or both) is more likely to be interested in existing relationships. Such relationships can continue in the future, leading to increased mutual benefits through better understanding and service customer needs (Anderson \& Narus, 1998; Nguyen \& Nguyen, 2014), as shown in Fig. 1. Therefore, the following hypotheses are formulated:

\section{$\mathrm{H}_{1}$ : Relationship value has a positive effect on retailer performance.}

The extant literature defines relationship age as the duration or length of time that a relationship between exchange partners has existed (Palmatier et al., 2006b), term relationship duration is also often used interchangeably (Kumar et al., 1995). Several studies measure the time-dependency effect of relational constructs in marketing perspective and socio-psychological (Doney \& Cannon, 1997; Verhoef et al., 2015). The relationship duration is an important characteristic of the exchange relationship that affects the supplier's behavior towards the distributor (Ganesan, 1994; Lusch \& Brown, 1996). Over time, long-term relationships become unshakeable from shorter relationships (Anderson \& Weitz, 1989), while unsatisfactory relationships end. To survive in relationship exchanges, partners will make adjustments in relationships to have a better relationship fit. The literature shows that business partners have more opportunities to gather information about each other and have intrinsic motivation to gather information to integrate information obtained into better representation in long-term relationships than partners in the early stages of the relationship. Over an extended period, partners in the relationship can predict behavior based on previous episodes, and it provides a framework for future transactions. Companies can modify the way to manage their relationships according to relational characteristics concerning the relationship (Yen \& Barnes, 2011) As in the initial stages 
of the relationship, partners face more significant uncertainty, losing investment, and seeking more relational benefits (Mungra \& Yadav, 2019). Therefore, the following hypotheses are formulated:

$\mathrm{H}_{2}$ : Relationship age strengthens the positive relationship between relationship value and performance in the manufacturerretailer relationship

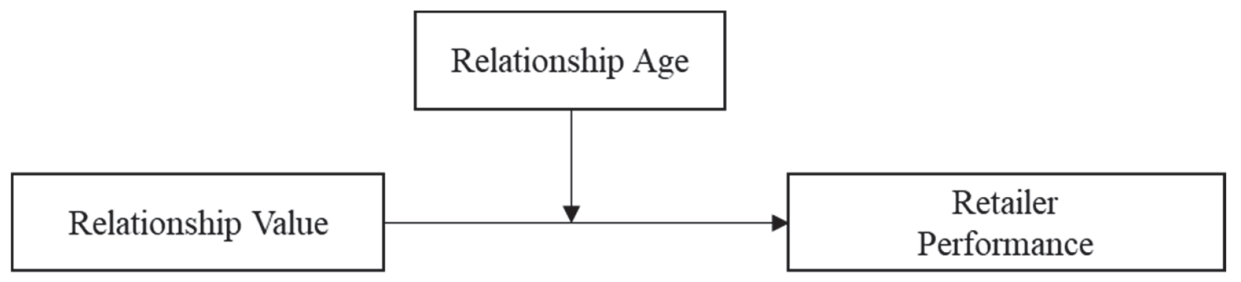

Fig 1. The conceptual model

\section{Methodology}

\subsection{Sampling and data collection}

This research conducted in a survey of decision-makers with positions supervisors, managers or owners, SMEs, or large retailers were operating in paint and chemicals store in Indonesia. The sample selection is implemented by purposive sampling using personal contacts and professional researchers at paint and chemicals store in 9 provinces in Indonesia (Banten, DKI Jakarta, West Java, Central Java, Yogyakarta (DIY), East Java, Bali, West Nusa Tenggara (NTB), and North Sumatera). The questionnaire was filled out and distributed through surveyors who interviewed decision-makers with minimal positions of supervisors. A sample of retailers were selected from a list provided by an independent marketing research firm. The store supervisors, managers, or owners who interact directly with suppliers served as the key informant for each retailer. These respondents indicated whether they were willing to participate in identifying manufacturers in our study. Our team contacted the store supervisors, managers, or owners who responsible for those retailers. Our team directly gave the questionnaires. We had received responses from 268 samples. After excluding incomplete questionnaires and respondents with inadequate knowledge about the relationship (less than an average of 3), we retained 255 data for further analysis. The interval scale used to indicate respondents' ratings is with a Likert interval scale of 1 to 5.

\subsection{Descriptive analysis}

The descriptive analysis describes the profile of the stores participating in this study and the respondents' profiles who answered the questionnaire. Descriptive statistical results aim to provide a general description of respondents' answers to the research questionnaire questions. Respondents who participated in this study had the following profiles: $72 \%$ men and $28 \%$ women; $70 \%$ of store owners and $30 \%$ of supervisors or managers. Furthermore, an analysis of respondents' answers done based on research variables. Store description based on the duration of relationship with the manufacturer, fewer than five years $(46 \%)$, and five or more than five years $(54 \%)$.

\subsection{Second-order construct specification}

Several constructs can be conceptually meaningful in the higher order of abstraction. As in this study, a high-level modeling approach will be the most suitable technique representing that structure. High order models can be positioned and can link manifest variables with each first-order latent variable which can then be linked with second-order latent variables. Contribution of each dimension to build a level higher can be assessed and described compared to all combining items together in a single composite score.

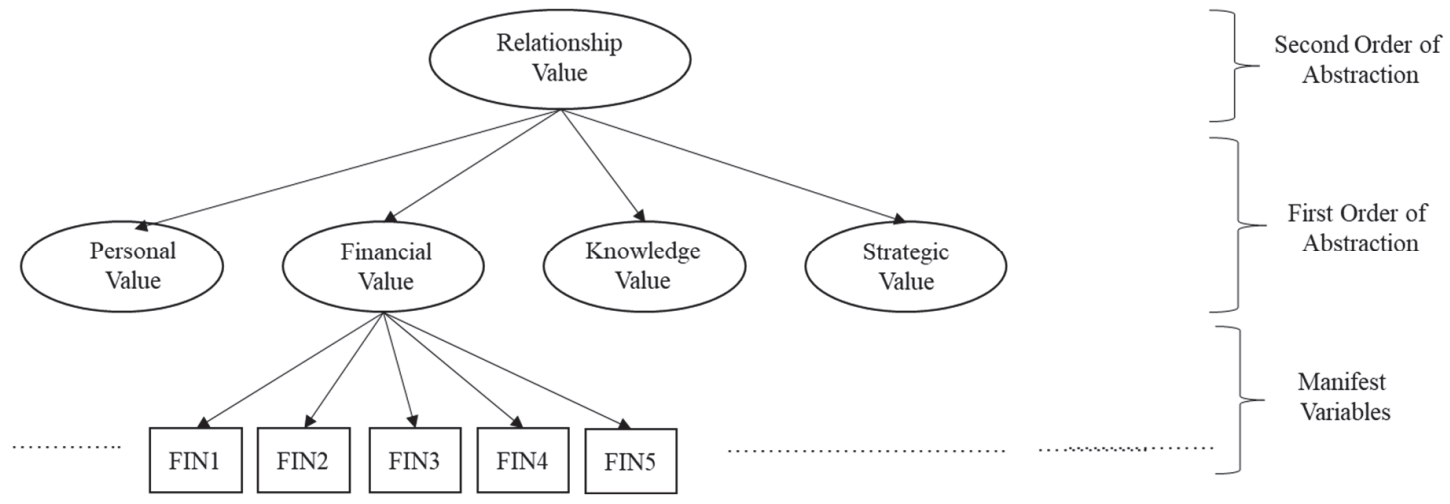

Fig 2. The hierarchy structures of relationship value and performance 
Relationship value is defined as the value creation from the interaction between manufacturers and retailers, where a mutual benefit occurs during cooperation, the congruence between expectations, and the results obtained. This research integrates the concept of value based on the relational approach, that relationship value in business is more than the concept of costs and benefits. The latent relationship value (RVA) variable is second-order confirmatory factor analysis $\left(2^{\text {nd }}\right.$ order CFA), measured from 4 variables ( $1^{\text {st }}$ order CFA): personal value (PER), financial value (FIN), knowledge value (KNO), and strategic value (STR). The hierarchy structures of relationship value and performance in this study (Fig. 2).

\subsection{Variables measurements}

The variables involved in this study as presented in Fig. 3. All of the constructs were supported by existing literature and were measured on a multi-item scale (5 points Likert scale ranging from "Strongly disagree" to "Strongly agree") except relationship age. To measure personal value (PER), we used five-item scale from Biggemann and Buttle (2012); Lefaix-Durand et al. (2009), Nguyen and Nguyen (2011). Five-item scale financial value (FIN) from Biggemann \& Buttle (2012) and LefaixDurand et al. (2009). Knowledge value (KNO) scale item measure from Ballantyne (2004), Biggemann \& Buttle ( 2012) and Skarmeas et al. (2015). To measure strategic value (STR), we used four-item scale from Biggemann \& Buttle (2012), Lewin et al. (2008) and Törrönen \& Möller (2003). Relationship age is an essential characteristic of the exchange relationship that affects the supplier's behavior towards the firm (Vu et al., 2020; Ganesan, 1994; Heide, 1994, Lusch \& Brown, 1996; Mungra \& Yadav, 2019).

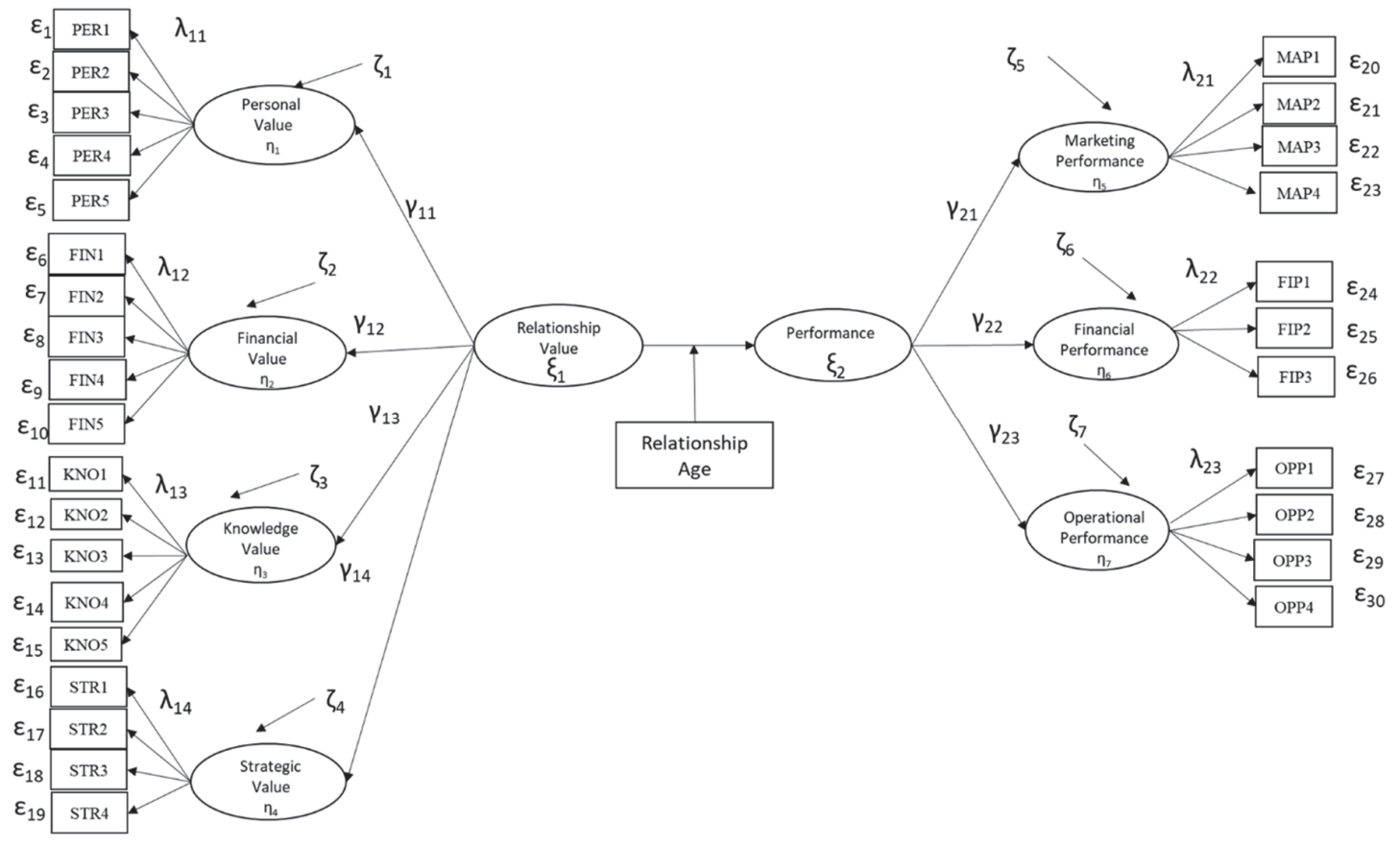

Fig. 3. The measurement model in the presence of relationship age as a moderator between relationship value and performance

Further, the latent variable performance is also measured as second-order confirmatory factor analysis, which is measured from 3 variables (i.e.) marketing performance (MAP), financial performance (FIP), and operational performance (OPP). Performance scale items, measure from (Gilbert \& Daniel, (2013a); Nyaga et al., (2010); Selnes \& Sallis, 2003; Cannon \& Homburg (2001), Gilbert \& Daniel (2013b), Nguyen \& Nguyen (2011), Selnes \& Sallis (2003), and Whipple et al. (2010). Relationship age is measured by a single item, i.e. "How long have you been doing business with this partner" (number of years, fewer than five years and five or more than five numbers of years into relationship). Business performance in the manufacturer-supplier relationship is also influenced by other factors outside the framework, like the firm's size that we have kept as a control variable for this study. The size of a firm impacts relationship outcomes (Brown et al., 2000; Mungra \& Yadav, 2019), in this study is measured by the store assets.

Before validating the integrated model, with all the covered research constructs, individual validation of the constructs was carried out. For individual validation of the constructs was assessed. From the analysis of the constructs' validity, all variables showed factor loadings higher than the minimum required (above 0.5 ). For the reliability of the constructs, all the presented values were above the recommended by calculating the comprised reliability. The results of all variables in this study have met the requirements shown in Table 3. 
Table 3

Descriptive statistics and measurement model evaluation

\begin{tabular}{|c|c|c|c|c|c|c|}
\hline Variable & Mean & Std Dev & SLF & t-value & Construct Reliability & Variance Extracted \\
\hline \multicolumn{7}{|l|}{ Relationship Value* } \\
\hline PER & 4.01 & 0.63 & 0.77 & 8.87 & 0.90 & 0.50 \\
\hline FIN & 3.82 & 0.73 & 0.75 & 11.40 & & 0.57 \\
\hline $\mathrm{KNO}$ & 3.88 & 0.71 & 0.96 & 12.48 & 0.87 & 0.57 \\
\hline STR & 3.80 & 0.67 & 0.89 & 12.96 & 0.91 & 0.72 \\
\hline \multicolumn{7}{|l|}{ Performance* } \\
\hline MAP & 3.88 & 0.67 & 0.88 & 11.74 & 0.86 & 0.93 \\
\hline FIP & 3.85 & 0.69 & 0.95 & 15.52 & 0.91 & 0.77 \\
\hline OPP & 3.91 & 0.67 & 0.86 & 11.74 & 0.89 & 0.69 \\
\hline
\end{tabular}

*second order dimension

\subsection{Data analysis}

After analyzing the measurement model, an analysis of the structural model is made according to the research model. To determine the effect of moderator variables on the relationship of relationship value and performance variables, which are then processed using SEM LISREL. SEM technique is used for several reasons, including: robust with little identification issues, focus on the confirmatory of the dependent variable, the model involves moderator variables, few indicators of model measurement, and measurements are reflective.

\section{Research result}

The structural measurement results of the model, as presented in Table 4, the relationship between the relationship value and performance is significant because the t-value is 8.38 , which is above the $t$-table value of 1.96. SEM was used to test theoretical model and hypotheses. The SEM results show that the model received an acceptable fit to the data: GFI $=0.980$, NFI $=0.990$, $\mathrm{RFI}=0.984, \mathrm{RMSEA}=0.040, \mathrm{SRMR}=0.021$. It is noted that no improper solution was found in any model.

Table 4

Structural model evaluation

\begin{tabular}{cccc}
\hline Relationship & Path Coefficient & t-Value & Conclusion \\
RVA $\rightarrow$ PFM & 0.56 & $8.38^{*}$ & Significant \\
\hline
\end{tabular}

$*_{\alpha}=5 \%$ (t-table: 1.96$)$

$\mathrm{N}=259(\mathrm{GFI}=0.980, \mathrm{NFI}=0.990, \mathrm{RFI}=0.984, \mathrm{RMSEA}=0.040, \mathrm{SRMR}=0.021)$

Furthermore, moderator variables' evaluation represents that relationship age does or not influence the relationship between relationship value and performance. For the evaluation of moderator variables, presented in Table 5 . The t-value of the relationship age for retailers fewer than five years $(n=100)$ and five or more than five years $(n=159)$, no difference is -0.195 , which is smaller than the t-table value of $1.96(\alpha=5 \%)$.

Table 5.

Evaluation on relationship age as moderator variable

\begin{tabular}{cccc}
\hline Relationship & Path Coefficient & t-Value & Conclusion \\
Rel. Age $\rightarrow$ PFM & 0.02 & $0.26^{*}$ & There is no difference \\
${ }^{*} \alpha=5 \%$ (t-table: 1.96$)$ & & \\
$\mathrm{N}=259(\mathrm{GFI}=0.956, \mathrm{NFI}=0.979, \mathrm{RFI}=0.971$, RMSEA $=0.057, \mathrm{SRMR}=0.029)$ &
\end{tabular}

\section{Discussion}

This research suggests the sequence of building blocks of relationship value and its impact on relational outcomes (performance). Realizing the importance of relationship between manufacturers and retailers, this study explores the role of relationship values on retailers' performance in the developing market, Indonesia. Using 259 paint and coatings retailers' sample, we found that the relationship value drives distributor performance. As such, this work contributes to areas of study that are less investigated in Indonesia. This finding provides several implications for academics and practitioners. Relationship value is significant in the relationship between the manufacturer and the distributor. This finding provides several implications for academics and practitioners. Relationship value is significant in the relationship between the manufacturer and the distributor. A high relationship value in the manufacturer-retailer relationship will improve retailer performance in sales, market share, and profits, based on manufactured products and beneficial for both parties. Retailers will be more likely to work more closely with manufacturers, allowing manufacturers to become main suppliers, generating multiple benefits for both parties. Therefore, manufacturers must pay attention to this study's results by investing more in their retailers' relationships. Therefore, manufacturers must pay attention to this study's results by investing more in relationships with their retailers. Relationship 
value in these studies is measured from four dimensions (i.e.) personal value, financial value, knowledge value, and strategic value. This research presents a new taxonomy to measure retailers' perceptions of building relationship values. The weight of each dimension in this study was calculated to determine which dimension gave the highest value. This study aims to better understand the more dominant dimensions in building relationship values between manufacturers and retailers in the paint industry. We find that the knowledge value has the highest standardized loading factor, which indicates that it is the main factor that drives the creation of relationship value between manufacturers and retailers. Knowledge value means creating and transferring knowledge, encouraging the creation of new ideas, sharing information, or more detailed market intelligence about market positioning as a form of finding demands of a growing market. Information about market conditions from the manufactures provides value for retailers in establishing cooperation. Complete information about new products remains a priority in creating relationship value because paint products continue to experience growth in quality and technology. More specifically, paint and chemical products have many variants that require a detailed understanding of the characteristics and advantages.

Several empirical studies have shown that knowledge is a dimension and driver of relationship value (Dyer \& Singh, 1998; Eggert \& Ulaga, 2002; Skarmeas et al., 2015; Westerlund \& Svahn, 2008; Wilson \& Jantrania, 1994). Previous research study by Dyer and Singh (1998) found that knowledge is an essential factor in generating competitive advantage. The relations of manufacturers-retailers of paint and coatings industries, exchange of information and discussions on developing new ideas focus on retailers in increasing cooperation. Data supports the model that relationship value variables affect performance. This study supported research by Nguyen and Nguyen (2011), stating that relationship value has a direct positive impact on business performance. Relationship value is defined as the achievement in real terms from the relationship results.

This study discusses performance more broadly by dividing into three performance measures (i.e.) marketing performance, financial performance, and operational performance. Financial performance evaluation is not complete enough to explain all the retailer's business performance. A more comprehensive analysis will help the manufacturer as an evaluation to formulate a strategy by better understand the more dominant dimensions in producing performance between manufacturers and retailers in the context of the paint industry. Financial performance is the primary dimension in measuring performance in this study. Economic success is an indicator of achieving the objectives of the relationship. Therefore, financial performance is an essential factor for retailers in establishing cooperation. A high relationship value perceived by a distributor leads to efficient transaction logistics management and marketing programs that contribute to the distributor's efficiency (Cannon \& Homburg, 2001; Nguyen et al., 2007; Nguyen \& Nguyen, 2011; Gandhi et al., 2018).

This study has examined the relationship age moderation factor, as the length of the relationship based on the period of the collaboration between the manufacturers-retailer. The hypothesis, relationship age will strengthen the influence of relationship value on creating business performance. Statistical test results, relationship age, does not strengthen the relationship between relationship value and sales collaboration. This study does not support previous study (Skarmeas et al., 2015), which found that the relationship duration will strengthen the influence in creating relationship value. The longer the relationship between the manufacturers-retailer will further increase the relationship value. Respondents in this study are retailers who have collaborated for more than one year, which is sufficient time to understand the manufacturer's characteristics. Creating relationship value between them, the length of time in cooperation has the same hope in retailers' eyes - both retailers who are relatively older and have a new partnership.

The indications match retailers' expectations and desired outcomes, the creation of mutually beneficial relationships, and opportunities to increase mutual benefits. Based on empirical studies, interviews with respondents represented by store owners obtained the following conditions. Today, more competitors in the paint and coatings industries are trying to become the store's main suppliers. This condition makes retailers looking for suppliers that have a more valuable relationship. Price is not the main focus of retailers but instead leads to a mutually beneficial relationship following retailers' expectations based on mutual agreement (Čater \& Čater, 2009; 2010). Second, the manufacturers's dominance in cooperative decision making is not desired by retailers. Retailers were easier to find other manufacturerss who are more cooperative. This condition becomes an opportunity for new players in the paint industry by exploiting other manufacturers relationships' weaknesses manufacturers who have been working partnership for fewer and more than five years are not affected by creating close manufacturers with the manufacturers.

In general, this study's empirical findings provide practical implications for the principal of the structural model of the factors driving the creation of relationship values that can serve to develop relationships with their retailers. More specifically, the manufacturers' manager can use this finding. Manufacturers need to identify factors that affect business performance has direct implications on strategy development; therefore, manufacturers are advised to differentiate themselves by building more relationship values with retailers.

\section{Conclusion}

This research has successfully revealed the significant influence of the relationship between relationship value and performance in business-to-business. Furthermore, it presented empirical research using a new taxonomy of relationship value and 
proposing operational indicators of the four dimensions of relationship value by measures the weight of each of the four dimensions of value attributed to a relationship between manufacturers and retailers. In the context of paint and coatings industries, strategic value more important than others. However, it turns out that the moderator variables, relationship age between manufacturers and retailers, i.e., in short-duration or long-duration, does not significantly impact their relationship. In addition to supporting previous studies related to the relationship value related to business performance, this research adds a better understanding for manufacturers and retailers to a partnership. The managers can use the implications mentioned above for improved decision-making in the business and industrial markets.

This study has several limitations. First, we only tested the paint and coatings industries model in several provinces in the west of Indonesia. Other industries and provinces may reveal different perspectives of value drivers. Therefore, future research should test in other industries and geographical regions to compare and contrast the similarities and differences among industries and regions, which help improve the generalizability of the results. The key informant in this study from a retailer's perspective, other members, might have different perspectives and emphases on value drivers (Nguyen \& Nguyen, 2011; Ulaga \& Eggert, 2006). Therefore, future research recommended collecting data from both sides of relationship members. Finally, this study relies heavily on the deductive approach. An inductive approach (i.e.) grounded theory can be used to explore relationship value and its determinants as a suitable alternative method.

\section{References}

Anderson, J.C. \& Narus, J. (1998). Business marketing: Understand what customers value. Harvard Business Review, November-December, 98601.

Anderson, E., \& Weitz, B. (1989). Determinants of continuity in conventional industrial channel dyads. Marketing Science, $8(4), 310-323$.

Anderson, E., \& Weitz, B. (2009). The use of pledges to build and sustain commitment in distribution channels. Journal of Marketing Research, 29(July), 1-15.

Anderson, J. C., Hakansson, H., \& Johanson, J. (1994). Dyadic business relationships within a business network context. Journal of Marketing, 58(4), 1.

Anderson, J. C., \& Narus, J. A. (1990). A model of distributor firm and manufacturer firm working partnerships. Journal of Marketing, 54(1), 42.

Ballantyne, D. (2004). Dialogue and its role in the development of relationship specific knowledge. Journal of Business and Industrial Marketing, 19(2), 114-123.

Biggemann, S., \& Buttle, F. (2012). Intrinsic value of business-to-business relationships: An empirical taxonomy. Journal of Business Research, 65(8), 1132-1138.

Brown, J.R., Dev, C.S. and Lee, D. J. (2000). Managing marketing channel opportunism: the efficacy of alternative governance mechanisms. Journal of Marketing, 64(2), 51-65.

Cannon, J. P., \& Homburg, C. (2001). Buyer - Supplier Relationships and. Journal of Marketing, 65(January), $29-43$.

Čater, B., \& Čater, T. (2009). Relationship-value-based antecedents of customer satisfaction and loyalty in manufacturing. Journal of Business and Industrial Marketing, 24(8), 585-597.

Cater, T., \& Cater, B. (2010). Product vs. relationship value in business-to-business manufacturing relationships. Transformations in Business and Economics, 9(2), 139-154.

Chang, K., \& Gotcher, D. F. (2010). Industrial marketing management conflict-coordination learning in marketing channel relationships : The distributor view. Industrial Marketing Management, 39(2), 287-297.

Cui, Y. Y., \& Coenen, C. (2016). Relationship value in outsourced FM services - value dimensions and drivers. February.

Day, G.S. (2000). Managing market relationships. Journal of the Academy of Marketing Science, 28(1), 24-31.

Doney, P. M., \& Cannon, J. P. (1997). An examination of the nature of trust in buyer-seller relationships. Journal of Marketing, 61(2), 35.

Dwyer, F. R., Schurr, P. H., \& Oh, S. (1987). Developing buyer-seller relationships. Journal of Marketing, $51(2), 11$.

Dyer, J. H., \& Singh, H. (1998a). Dyer, J. H., \& Singh, H. (1998). The relational view: Cooperative strategy and sources of interorganizational competitive advantage. Academy of Management Review, 23(4), 660-679.

Dyer, J. H., \& Singh, H. (1998b). The relational view: Cooperative strategy and sources of interorganizational competitive advantage. Academy of Management Review, 23(4), 660-679.

Eggert, A., \& Ulaga, W. (2002). Customer perceived value: A substitute for satisfaction in business markets? Journal of Business \& Industrial Marketing, 17(2-3), 107-118.

Ford, D., \& Mcdowell, R. (1999). Developing business relationships. Industrial Marketing Management, 28, 429-442.

Frazier, G. L. (2009). Physical distribution and channel management: A knowledge and capabilities perspectives. April, 2336.

Gandhi, S., Sachdeva, A., \& Gupta, A. (2018). Distributor service quality in Indian SMEs: A bi-directional customer perspective. Uncertain Supply Chain Management, 6(4), 335-356.

Ganesan, S. (1994). Determinants of long-term orientation in buyer-seller relationships. Journal of Marketing, 58(2), 1-19.

Geyskens, I., Steenkamp, J.-B. E. ., \& Kumar, N. (1998). Generalizations about trust in marketing channel relationships using meta-analysis. International Journal of Research in Marketing, 15(3), 223-248.

Gilbert, N., \& Daniel, F. (2013a). Power asymmetry, adaptation and collaboration in dyadic relationships Involving A 
Powerful Partner. Journal of Supply Chain Management, 49(3), 42-65.

Gilbert, N., \& Daniel, F. (2013b). Power asymmetry, adaptation and collaboration in dyadic relationships involvin. Journal of Supply Chain Management, 49(3), 42-65.

Glynn, M. S., Brodie, R. J., \& Motion, J. (2012). The benefits of manufacturer brands to retailers. European Journal of Marketing, 46(9), 1127-1149.

Heide, J. B. (1994). Interorganizational governance in marketing channels. Journal of Marketing, $58(1), 71$.

Herlambang, T., Batt, P. J., \& McGregor, M. J. (2006). Developing an effective food chain management in a developing country: A case study on Manalagi Mango Fruit supply chain in Indonesia. 16th Annual IAMA Food \& Agribusiness Forum, Symposium \& Case Conference, May 2014, 1-21.

Homburg, C., Kuester, S., Beutin, N., \& Menon, A. (2005). Determinants of customer benefits in business-to-business markets: A cross-cultural comparison. Journal of International Marketing, 13(3), 1-31.

Kang, J., Asare, A. K., Brashear-Alejandro, T., Granot, E., \& Li, P. (2018). Interorganizational drivers of channel performance: a meta-analytic structural model. Journal of Business and Industrial Marketing, 33(2), $183-195$.

Kotler, P. (2000). Marketing Management Millenium Edition. Prentice-Hall, 23(6), 188-193.

Kumar, N., Scheer, L. K., \& Steenkamp, J.-B. E. M. (1995). The effects of supplier fairness on vulnerable resellers. Journal of Marketing Research (JMR), 32(1), 54-65.

Lapierre, J. (2005). Emerald Article : Customer-perceived value in industrial contexts Customer-perceived value in industrial contexts. 2000.

Lefaix-Durand, A., Kozak, R., Beauregard, R., \& Poulin, D. (2009). Extending relationship value: Observations from a case study of the Canadian structural wood products industry. Journal of Business and Industrial Marketing, 24(5), 389-407.

Leonidou, L. C., Samiee, S., Aykol, B., \& Talias, M. A. (2014). Antecedents and outcomes of exporter-importer relationship quality: Synthesis, meta-analysis, and directions for further research. Journal of International Marketing, 22(2), 21-46.

Levitt, T. (1981). Marketing intangible products and product. Harvard Business Review, 59(3), 37-44.

Lewin, J., Barry, J., \& Terry, T. S. (2008). Empirical study of relationship value in industrial services. Journal of Business \& Industrial Marketing, 23(4), 228-241.

Li, L. Y. (2010). Antecedents of principal-agent relationship value: The differential impact of social capital and dynamic learning factors. Journal of Marketing Channels, 17(4), 313-338.

Lindgreen, A., \& Wynstra, F. (2005). Value in business markets: What do we know? Where are we going? Industrial Marketing Management, 34(7 SPEC. ISS.), 732-748.

Lusch, R. F., \& Brown, J. R. (1996). Interdependency, contracting, and relational behavior in marketing channels. Journal of Marketing, 60(4), 19-38.

Marx, K. (1967). Capital A Critique of Political Economy: Vol. I. New York: International publishers.

Mehta, R., Larsen, T., Rosenbloom, B., \& Ganitsky, J. (2006). The impact of cultural differences in U. S . business-to-business export marketing channel strategic alliances. 35, 156-165.

Mungra, Y., \& Yadav, P. K. (2019). The mediating effect of satisfaction on trust-commitment and relational outcomes in manufacturer-supplier relationship. Journal of Business and Industrial Marketing, 35(2), 219-230.

Nguyen, T.T.M., Barrett, N.J. and Nguyen, T. D. (2007). The role of market and learning orientations in relationship quality: evidence from Vietnamese exporters and their foreign importers. Advances in International Marketing, 17, $107-133$.

Nguyen, T. D., \& Nguyen, T. T. M. (2011). Enhancing relationship value between manufacturers and distributors through personal interaction: Evidence from Vietnam. Journal of Management Development, 30(4), 316-328.

Nguyen, T. T. M., \& Nguyen, T. D. (2014). The impact of cultural sensitivity and information exchange on relationship quality. Marketing Intelligence and Planning, 32(7), 754-768.

Nyaga, G. N., Whipple, J. M., \& Lynch, D. F. (2010). Examining supply chain relationships : Do buyer and supplier perspectives on collaborative relationships differ? Journal of Operations Management, 28(2), 101-114.

Palmatier, R. W., Dant, R. P., Grewal, D., \& Evans, K. R. (2006a). Factors Influencing the Effectiveness of Relationship Marketing: A Meta-Analysis. Journal of Marketing, 70(4), 136-154.

Palmatier, R. W., Dant, R. P., Grewal, D., \& Evans, K. R. (2006b). Factors influencing the effectiveness of relationship marketing: A meta-analysis. Ssrn, 70(October), 136-153.

Payne, A. F., Storbacka, K., \& Frow, P. (2008). Managing the co-creation of value. Journal of the Academy of Marketing Science, 36(1), 83-96.

Peter M, B. (1965). Exchange and Power in Social Life (Vol. 30, Issue 5). American Sociological Association.

Pimpa, N. (2008). Relationship value in thai business-to-business marketing. Journal of Asia-Pacific Business, 9(3), $235-247$.

Puspitawati, E. (2011). Determinants of trust in the Indonesian potato industry: a comparison among groups of potato farmers. The 55th Annual Conference of the Australian Agricultural and Resource Economic Society (AARES).

Ritter, T., \& Walter, A. (2012). More is not always better: The impact of relationship functions on customer-perceived relationship value. Industrial Marketing Management, 41(1), 136-144.

Rosenbloom, B. (2013). Marketing channels: a management view. South-Western, Cengage Learning. Eighth International Edition.

Ruiz-Martinez, A., Gil-Saura, I., \& Frasquet, M. (2018). Axes of relationship value between manufacturers and retailers. Management Decision, 56(8), 1716-1733.

Selnes, F., \& Sallis, J. (2003). Promoting relationship learning. Journal of Marketing, 67(3), 80-95.

Setyawan, A. A., Dharmmesta, B. S., Purwanto, B. M., \& Nugroho, S. S. (2013). Model of relationship marketing and 
asymmetry power in Indonesia retail industry. 13th Annual ASEAN Graduate Business and Economics Program (AGBEP) Network Meeting and Conference, II(4), 108-127.

Singh, H., Garg, R., \& Sachdeva, A. (2018). Supply chain collaboration: A state-of-the-art literature review. Uncertain Supply Chain Management, 6(2), 149-180.

Skarmeas, D., Zeriti, A., \& Baltas, G. (2015). Relationship value: Drivers and outcomes in international marketing channels. Journal of International Marketing PrePrint, Une, 1-44.

Stern, L. W., \& Palmatier, R. W. (2014). Marketing Channel Strategy (8th ed.). Pearson.

Storbacka, K. T. S. and C. G. (1994). Managing customer relationships for profit: The dynamics of relationship quality. International Journal of Service Industry Management, 5(5), 21-38.

Sukresna, I. M. (2015). Marketing channel connectivities within the Indonesian manufacturing sector. Journal of Economics, Business and Management, 3(10), 1004-1008.

Törrönen, P., \& Möller, K. (2003). Business suppliers’ value creation potential: Empirical analysis. Industrial Marketing Management, June, 1-11.

Ulaga, W., \& Eggert, A. (2005). Relationship value in business markets: The construct and its dimensions. Journal of Business-to-Business Marketing, 12(1), 73-99.

Ulaga, W., \& Eggert, A. (2006). Relationship value and relationship quality: Broadening the nomological network of businessto-business relationships. European Journal of Marketing, 40(3-4), 311-327.

Verhoef, P. C., Kannan, P. K., \& Inman, J. J. (2015). From multi-channel retailing to omni-channel retailing. Introduction to the special issue on multi-channel retailing. Journal of Retailing, 91(2), 174-181.

Vu, T., Tran, H., Le, T., Nguyen, M., \& Duong, B. (2020). Relationship between supply chain activities in Vietnamese retail business enterprises. Uncertain Supply Chain Management, 8(2), 321-33

Walter, A., Ritter, T., \& Gemünden, H. G. (2001). Value creation in buyer-seller relationships - Theoretical considerations and empirical results from a supplier's perspective. Industrial Marketing Management, 30, 365-377.

Weitz, B. A., \& Jap, S. O. (1995). Relationship marketing and distribution channels. Journal of the Academy of Marketing Science, 23(4), 305-320.

Werner, J., Reinartz, \& Kumar, V. (2003). The impact of customer relationship characteristics on profitable lifetime duration. Journal of Marketing, 67(1), 77-99.

Westerlund, M., \& Svahn, S. (2008). A relationship value perspective of social capital in networks of software SMEs. Industrial Marketing Management, 37(5), 492-501.

Whipple, J. M., Lynch, D. F., \& Nyaga, G. N. (2010). A buyer's perspective on collaborative versus transactional relationships. Industrial Marketing Management, 39(3), 507-518.

Williamson, O. E. (1979). Transaction-cost economics: The governance of contractual relations. Journal of Law and Economics, 22(2), 233-261.

Wilson, D. T., \& Jantrania, S. (1994). Understanding the value of a relationship. Asia-Australia Marketing Journal, 2(1), 5566.

Wouters, M., Anderson, J. C., \& Wynstra, F. (2005). The adoption of total cost of ownership for sourcing decisions - a structural equations analysis. Accounting, Organization and Society, 30, 167-191.

Yen, D., \& Barnes, B. (2011). Analyzing stage and duration of Anglo-Chinese business-to-business relationships. Industrial Marketing Management, 40(3), 346-357. 
Appendix

Scale Item After Purification

\begin{tabular}{|c|c|c|c|c|}
\hline Dimension & & Questionnaire Items & Loading Factor & t-value \\
\hline \multicolumn{5}{|l|}{ *Relationship Value } \\
\hline \multirow[t]{5}{*}{ Personal Value } & PER1 & Assignment Certainty & 0.52 & 8.15 \\
\hline & PER2 & Availability & 0.52 & 8.06 \\
\hline & PER3 & Friendliness & 0.69 & 11.33 \\
\hline & PER4 & Ease of interaction & 0.82 & 13.99 \\
\hline & PER5 & Decision making & 0.62 & 10.02 \\
\hline \multirow[t]{5}{*}{ Financial Value } & FIN1 & Willingto pay more & 0.72 & 12.34 \\
\hline & FIN 2 & Open to negotiation & 0.86 & 15.62 \\
\hline & FIN 3 & Flexibility & 0.54 & 8.67 \\
\hline & FIN 4 & Cost advantage & 0.50 & 7.96 \\
\hline & FIN 5 & Meet budget target & 0.70 & 11.90 \\
\hline \multirow[t]{4}{*}{ Knowledge Value } & KNO1 & Market intelligent & 0.92 & 19.20 \\
\hline & KNO2 & Innovation & 0.98 & 21.24 \\
\hline & KNO 3 & Information sharing & 0.77 & 14.68 \\
\hline & KNO4 & Idea-generation & 0.69 & 12.40 \\
\hline \multirow[t]{4}{*}{ Strategic Value } & STR1 & Long term planning & 0.80 & 13.86 \\
\hline & STR2 & Supply chain strategy & 0.74 & 12.63 \\
\hline & STR3 & Aligned goal orientation & 0.81 & 14.04 \\
\hline & STR4 & Extended relationship & 0.87 & 5.59 \\
\hline \multicolumn{5}{|l|}{ *Performance } \\
\hline \multirow[t]{4}{*}{ Marketing Performance } & MAP1 & Satisfaction & 0.68 & 11.18 \\
\hline & MAP2 & Market share growth & 0.75 & 12.77 \\
\hline & MAP3 & Customer growth & 0.77 & 13.06 \\
\hline & MAP4 & Awareness & 0.71 & 11.80 \\
\hline \multirow[t]{3}{*}{ Financial Performance } & FIP1 & Sales achievement & 0.86 & 14.63 \\
\hline & FIP2 & Sales growth & 0.70 & 11.67 \\
\hline & FIP3 & Profitabilty growth & 0.76 & 12.84 \\
\hline \multirow[t]{4}{*}{ Operational Performance } & OPP1 & Logistic effectivity & 0.67 & 11.41 \\
\hline & OPP2 & Delivery performance & 0.57 & 9.50 \\
\hline & OPP3 & Inventory level & 0.92 & 17.43 \\
\hline & OPP4 & Operational efficiency & 0.77 & 13.80 \\
\hline
\end{tabular}

*second order dimension

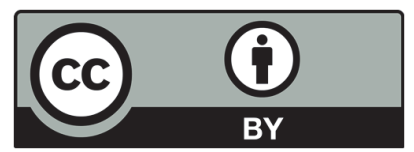

(C) 2020 by the authors; licensee Growing Science, Canada. This is an open access article distributed under the terms and conditions of the Creative Commons Attribution (CC-BY) license (http://creativecommons.org/licenses/by/4.0/). 